Chapman University

Chapman University Digital Commons

Education Faculty Articles and Research

College of Educational Studies

2015

\title{
Wrestling With Expectations: An Examination of How Asian American College Students Negotiate Personal, Parental, and Societal Expectations
}

Michelle Samura

ChapmanUniversity, samura@chapman.edu

Follow this and additional works at: http://digitalcommons.chapman.edu/education_articles

Part of the Asian American Studies Commons, Bilingual, Multilingual, and Multicultural Education Commons, and the Higher Education Commons

\section{Recommended Citation}

M., Samura. (2015). "Wrestling With Expectations: An Examination of How Asian American College Students Negotiate Personal, Parental, and Societal Expectations." Journal of College Student Development, 56(6), 602-618.

This Article is brought to you for free and open access by the College of Educational Studies at Chapman University Digital Commons. It has been accepted for inclusion in Education Faculty Articles and Research by an authorized administrator of Chapman University Digital Commons. For more

information, please contact laughtin@chapman.edu. 


\section{Wrestling With Expectations: An Examination of How Asian American College Students Negotiate Personal, Parental, and Societal Expectations}

\section{Comments}

This article was originally published in Journal of College Student Development, volume 56, issue 6, in 2015.

\section{Copyright}

ACPA - College Student Educators International 


\title{
Wrestling With Expectations: An Examination of How Asian American College Students Negotiate Personal, Parental, and Societal Expectations
}

\author{
Michelle Samura
}

This research draws on a broader study that situates Asian American college students within larger sociohistorical and political contexts. I examined Asian American college students' experiences and what it means to be "Asian American" in and through these experiences. Two types of expectations emerged from the data: students' internal expectations - the expectations that they have for themselves as well as their college and postcollege experiences, and external expectations from family and society. The various ways that students negotiate internal and external expectations translate into particular understandings of freedom and possibility they carry into college. I also discuss students' precollege racial awareness since the combined meanings of Asian American racial identity and higher education with which students enter college subsequently influence their college experiences and impacts racial identity formation during their college years.

Students enter higher education with a range of different views about themselves, other people, and the world in which they live. They come to college with racial identities and perspectives on race that have been shaped by their families, peer groups, and communities (Hurtado, Milem, Clayton-Pedersen, \& Allen, 1998). Existing research on students' expectations have focused on the relationship between college students' expectations and behaviors (e.g., Miller, Bender, \& Schuh, 2005; Schilling \& Schilling, 2005), disconnects between high school and college (e.g., Keup, 2007; Smith $\&$ Wertlieb, 2005), and connections between precollege traits and different students' various educational trajectories (e.g., Terenzini, Springer, Yaeger, Pascarella, \& Nora, 1996).

Although there has been a significant amount of research on students' expectations of college, there remains limited discussion dedicated to specific racial groups, particularly Asian Americans. There are a few notable studies. For example, Kao (2002) found that immigrant parents tend to have higher expectations of their children than nonimmigrant parents, and Asian parents have particularly high aspirations for their children. Relatedly, Feliciano (2006) examined the relationship between Asian American parents' expectations and Asian American youths' aspirations and found that Asian American college students tend to view their parents' expectations of them as higher than they actually are. Feliciano also found that the premigration socioeconomic status of Asian American college students' parents is positively correlated with students' perceptions of their parents' expectations.

Focusing on the impact of ethnic culture and class, Louie (2004a) examined how Chinese American students at two colleges, one elite and the other nonelite, understood the role of family in their college choices. Despite differences in students' class and educational background, Louie argued, the immigrant family was a significant influence on

Michelle Samura is Assistant Professor of Educational Studies and Coordinator of Student and Community Engagement at Chapman University. 
her participants' understanding of education. The various Chinese American students in her study created similar narratives in which Asian American parents play a significant role, specifically in the academic aspects of their children's lives:

The similarities lie in the language they use to speak of this role and in the particulars they saw in the role itself, like hard work, strict monitoring of children, the prestige of the college one attended, and the career aspirations held by parents. (p. xxvi)

Louie further suggested that these shared narratives were not viewed as solely related to Chinese culture, rather a commonality among Asians. Louie (2004b) also found that her participants' parents placed a significant amount of pressure on their children to enter "practical" majors in order to help support the family and/or hedge potential discrimination due to race or immigration status.

While some research, such as the studies mentioned above, have examined family expectations, there is little research on other sources of Asian American college students' expectations, apart from family or parents. Moreover, there is a lack of research on the implications of these various expectations. As such, the purpose of this article is to paint a picture of the variety of expectations and aspirations with which many Asian American college students currently wrestle. In addition to highlighting the various types and sources of expectations, this article also focuses on how students make sense of and negotiate expectations. Particular emphasis is placed on the factors that contribute to a process in which students engage, as opposed to a phase through which students pass. These processes of negotiating expectations underscore the complexities of Asian American college students' experiences as they already manage, and continue to manage, a variety of factors as they enter college.

\section{RESEARCH DESIGN \\ Research Questions and Theoretical Frameworks}

This article draws on a broader study that situates Asian American college students within larger sociohistorical and political contexts. I examined Asian American college students' experiences and what it means to be "Asian American" in and through these experiences. The guiding research questions were: How do Asian American students navigate through physical and social spaces of higher education? and How do Asian American college students understand what it means to be "Asian American" today?

The study was framed by a Blumerian understanding of symbolic interactionism to examine how interactions among people and spaces recreate meanings of race. Instead of locating meaning in the intrinsic make up of an individual, Blumer (1969) argued that meaning emerges from interactions between people; thus, an individual engages in an interpretative process in which she determines meaning and uses those meanings to determine action. In the context of this study, a symbolic interactionist approach emphasizes the reflexive and self-reflexive capacity of students. This approach enabled me to analyze the meanings, particularly meanings of Asian American racial identity, that emerged from the interactions between students' internal and external expectations.

This study also utilized critical spatial perspectives (e.g., Delaney, 2002; Knowles, 2003; Lipsitz, 2007; Massey, 1994) to examine racial inequality by focusing on issues of power on individual and structural levels and in material and intangible forms. Through a spatial lens, researchers can examine what types of interactions occur as well as where they occur. 


\section{Participants}

I use a nonprobability purposive sampling technique to select participants who were undergraduate students and who self-identified as Asian or Asian American.* At the time of data collection (March 2007) the majority of students at West University (a pseudonym) were White (52\%), while 16\% identified as Asian Pacific Islander. Participants were recruited through verbal announcements made in classes, flyers posted around campus, and e-mail announcements sent directly to campus organizations and through Facebook pages. Snowball sampling allowed for further recruitment of participants. A total of 36 students participated in this study-18 interviewees and 19 photo journalers, with 1 participant doing both an interview and photo journal.

Of the pool of student participants, $31 \%$ were male and $69 \%$ were female. The majority of participants were upperclassmen (i.e., third-year or fourth-year students). Although specific data regarding family income were not collected, nearly all of the students self-identified their families as either "middle class" or "upper middle class." Sixty-seven percent were born in the United States, and English was the primary language for $78 \%$ of the participants. The majority of the student participants self-identified as first generation (i.e., born in a country other than the US) or second generation (i.e., born in the US with at least one parent who was born in another country). Ten of the 36 participants identified as first generation (28\%), 1 identified as 1.5 generation (3\%), and 17 identified as second generation (47\%). Approximately $28 \%$ of the participants self-identified as mixed race or mixed ethnicity. Sixteen of the 36 participants (44\%) self-identified as Chinese or partChinese. The participant pool also included 7 students who self-identified as Japanese (19\%), 7 who self-identified as Vietnamese (19\%), 6 who self-identified as Filipino (17\%), 2 each (6\%) who self-identified as Cambodian and Korean, and 1 each (3\%) who self-identified as Taiwanese, Laotian, Thai, and Guamanian.

\section{Data Collection and Analysis}

Data collection took place during the 2007-08 academic year at West University, a large public research institution on the West Coast of the United States. Semistructured interviews (Kvale, 1996) lasted from 1 to 2 hours, and I used an interview guide with four topic sections. The first section explored how students spent their time and how they related to various spaces of West University. The second section focused on students' academic development and engagement. The third section examined students' civic engagement and development, including involvement in campus organizations, political affiliations, and religious preferences. Finally, the fourth section focused on students' personal development.

Photo journals were kept by 19 students

\footnotetext{
* My initial call for participants was for West University undergraduate students who self-identified as Asian American; however, I came to realize that by omitting the category Asian, I might miss a number of firstgeneration students whom I would consider Asian American. In fact, this predicament (i.e., how to categorize/ label people and how people categorize/label themselves), even among potential participants, was reflective of the dilemma that I was researching: Who fits into the Asian American category? Who wants to fit in? And in what contexts do they fit? I also began to question the point at which an Asian becomes Asian American; for example, does a student who is classified as Asian or even an international or foreign student and then stays in the US or returns to the US after college remain Asian? If and when does that Asian individual transition into the category of Asian American? In the end, I expanded the call for participants to include both Asian and Asian American. Offering students the chance to self-identify through a broader call for participants was the way that I chose to move forward, even though these issues still remained.
} 
for a minimum of 1 week. Students were asked to take pictures of their everyday lives and of things, people, and places that have meaning and significance to them. In addition to the general guidelines, I also gave students a shooting script with 8 questions. A shooting script is a list of topics or questions that can be examined through photographs (Suchar, 1997). Students' shooting script questions were taken directly from my interview guide. Representative questions included: Where do you spend the most time? Where, when, and with whom do you feel the most comfortable? and What aspects of your identity seem to matter the most at West University? Students answered the shooting script questions through photographs and took notes on these images to provide context and further insight into what they captured and the meanings of their images.

The visual methods (e.g., photo journals; Collier \& Collier, 1986; Suchar, 1997) enabled me to view students' experiences as close to their perspectives as possible. Photographs helped elicit responses that other forms of inquiry, such as traditional interviews or surveys, may overlook. The process of photo journaling enabled students to incorporate more of their contexts into their responses. As opposed to a one-time interview, students had more time to consider questions and were able to use different tools to create and represent their responses. These sources of data also helped me develop a clearer picture of the campus landscape - the nature of the physical space as well as the various types of social interactions taking place in these spaces — and how Asian American students are navigating through and negotiating within these spaces. Additionally, the notes that students provided me regarding pictures they took helped me better understand the intentions behind and contexts surrounding the images.

Interview data were analyzed using an open-ended, ad hoc coding technique (Kvale,
1996; Strauss \& Corbin, 1998). In addition to providing a way for me to report and describe what interviewees share, this technique enabled me to analyze students' interactions and the meanings created in and through the interactions. Photographs and related photo journal notes were also coded and thematic and content analyses were used to analyze the photo journals (Collier \& Collier, 1986; Suchar, 1997). Data from the interviews, photographs, and photo journal notes were triangulated to determine which code categories and themes were most pervasive: these serve as the basis of the topics discussed in this article. The examples provided throughout the article, such as interviewee quotes, were selected because they are indicative of patterns of particular student views and beliefs found in the data.

\section{LIMITATIONS}

This study was meant to provide a snapshot of the landscape of higher education with its racial structures, racial spaces, and racial transformations. By no means does this investigation represent a comprehensive analysis of the phenomenon, nor am I suggesting that findings from this study are transferrable to other settings. While it would be useful to extend this investigation across a number of other sites to see if similar issues emerge, I also believe that the issues examined and questions posed throughout this study are extremely valuable in and of themselves. Additionally, the emergent issues, especially when situated within larger sociohistorical contexts, seem to suggest that they are a part of larger patterns. I imagine that the occurrences at West University are also taking place at other campuses.

\section{FINDINGS AND DISCUSSION}

Data from the interview and photo journals revealed students in this study wrestled with 


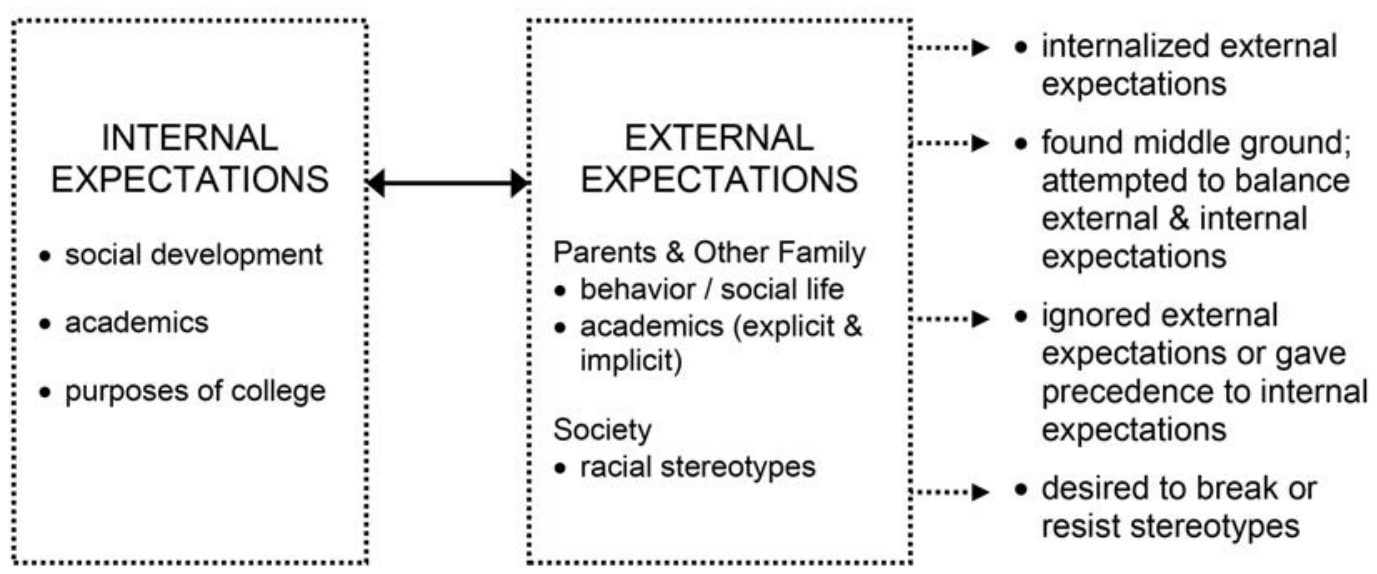

Figure 1. Negotiating Internal and External Expectations

both internal and external expectations. I made the distinction between the two types of expectations based upon the ways students discussed their precollege orientations and their expectations of college and postcollege life. Internal expectations encompass individual students' ideas of college life as well as their aspirations for who they hope to be, both during and as a result of college. External expectations, by contrast, refer to the people, ideas, and larger social forces that impact, guide, and shape students and their choices.

Sources of expectations vary, and expectations may be implicit and unspoken while others were explicitly and repeatedly verbalized. Internal expectations were rooted in interests and passions. Some external expectations were from students' families and had been instilled in these students since childhood. Other external expectations were connected to broader US racial politics and shifting, though persistent, meanings of Asian American racial identity.

Although internal and external expectations differ, they certainly are not inseparable. Many external expectations are internalized by students or play a significant role in the formation of students' internal expectations. Still other expectations blurred the line between what students wanted for themselves and what others wanted for them. In fact, a number of the students in this study talked about the overlap of external and internal expectations, including several who suggested that they wanted what their parents wanted. Figure 1 illustrates the different types and sources of expectations and the four most prevalent outcomes of interactions between students' internal and external expectations.

\section{Internal Expectations}

The students in this study entered college with various hopes, dreams, and aspirations of who they wanted to become and what they wanted to do. These personal expectations pertained to their college experiences and postcollege life. While students expressed a number of different expectations based on their own personality types and experiences, there were three notable internal expectations that students frequently talked about. First, several students shared strong desires to develop their social skills and expand their social circles. This was often in reaction to their isolated, sheltered, or introverted experiences during high school. Another common theme was students' expectations of college social life, referring to the varying types and levels of 
activities in which students imagined they would engage. The majority of students had some level of expectation of what college social life (e.g., parties, substance exploration) would be like, though most of them did not expect the extent to which these activities would dominate college life. Second, many of the students commented on their expectations of what academic life would be like. Some expected college courses to be extremely difficult, while others, a number of whom excelled in high school, expected academic life to be easy. And third, students commented on the purposes of college, which for many of them was to be a time for self-discovery: college, in their minds, would serve as a space to figure out what they wanted to do, who they wanted to be, and/or to prepare them for their postcollege endeavors.

Social Development. Several students shared that they had hoped to broaden their social lives while in college. College seemed like the appropriate time to meet more people and make friends. For these students, college would serve as a fresh start as they anticipated becoming "more social." When I asked Lisa (all participant names are pseudonyms), a thirdgeneration Japanese American, about what she had hoped to get from attending college, her first response was regarding her social life. Lisa talked about how she had wanted to meet more people, be more assertive, and be able to express herself verbally. These new ways of engaging socially would be a break from her previous tendencies in high school to be very passive and quiet. Lisa explained:

Having two older brothers who already went through college, I saw them and I thought, "Gosh, I want to do the same thing. I want to get involved. I want to be able to interact with my professors." And, so, I guess that's what I wanted out of it. That and also ... having a sense of community.
Finding a "sense of community" or a group of people with whom she felt like she belonged was a desire commonly shared among participants. A number of students felt like college would be a new start, a space of possibility and opportunity where they could reinvent themselves and become what they had been too busy, too protected, or too scared to be. In Lisa's case this meant something as seemingly simple as speaking more and making friends.

Another part of students' social development was their engagement in various types of social activities. While some of the students who wanted to work on their social lives during college primarily focused on having more friends, other students talked about their views of college as a time to explore and experiment. This often translated into further developing their social circles and experiences through parties and substance exploration. It was unclear as to how much students initially intended to partake in this aspect of college. Many of the students in this study shared about how they did not expect the extent to which students engaged in the drinking and partying, even though almost all of them had heard about West University's reputation for these activities. Nevertheless, the numerous photo journal images of bottles of alcohol as well as pictures of groups of friends drinking, at bars, or gathering before heading out to bars suggested that these activities ended up being a part of students' social lives, though more so for some than others.

Missy, a second-generation Chinese, even chose to take a picture titled "Crushing Things Into a Fine Powder" as a way of depicting the newfound freedoms which many students partake in. In the picture, Missy is leaning over a small mound of white powder on a table. She explained:

[This city], as well as every other college, 
is known for the times that adolescents experiment with drugs. When I first came to West University I was surprised because I'd never considered doing anything illegal, but it seems that everyone here has done something.

Missy later noted, "It's not real. It was a joke." What is important to note here are the ways in which students viewed college as a space of freedom. These activities, both expectations of engagement and actual engagement, were another aspect of college social life through which students could partake of this newfound freedom. In these, students experienced West University as only intermittently academically challenging.

Academics. Students indicated that they had mixed expectations of what academics in college would be like. For the students who excelled academically in high school, college courses were assumed to be easy. Other students expected college courses to be extremely difficult. In many cases the expectation of high levels of academic difficulty was informed by friends, teachers, and academic advisors who warned them about how hard college courses would be, at least in comparison to high school. Some of these students found that college was not as academically difficult as they had expected.

Students also had different views of the importance of academics. A number of students considered academics as very important, several participants stating that the academic aspect of college was the primary reason for attending college. Several other students shared how the importance of academics lessened over time. I will discuss how students' expectations align (or not) with their actual experiences in college space. This examination will include how students made sense of the unexpected academic difficulties, particularly in courses for their majors: students frequently have to remake their expectations or reposition themselves.

Purposes of College. In addition to addressing the social and academic aspects of college life, a number of students shared about what they generally expected to get from attending college. In particular, students viewed college as a space for self-discovery. When asked about what she hoped to get from attending West University, Mika, a secondgeneration Japanese and sixth-generation Irish American, responded:

Well, an education. I wanted to just figure out what I wanted to do-like, use this time to figure out my job and stuff like that. But also, I see college as a learning experience about yourself, and ... it seemed to me ... you meet new people and you're getting older and you're maturing, so I wanted to learn more about myself as well.

Peter, a second-generation Chinese, gave a similar response: "A degree, I guess. And just figure out what I wanted to do." Both Mika and Peter began their reply with an outcome related to academics. Mika hoped to get an education. Peter expected to get a degree. But then both of them followed up by adding that they wanted to "just figure out" what they wanted to do.

Many students also shared about college being a means to an end, namely a respectable, hopefully lucrative job. RC, a first-generation Filipino, even spoke about his initial expectations of emerging from college with the skills and resources to make money and help his family:

Since I was a child I've always wanted to like become something. I've always wanted to ... take my family out of ... poverty. ... I'm the youngest child out of eight, and I'm the first to attend college and graduate college. So coming into college I think that I just wanted to bring my family into another level. ... That was my motive. 
After entering college RC soon realized that it would not be as easy as he had anticipated to excel academically. Although he still wanted to help his family, his perspective on the purposes of college had expanded. As a graduating senior, he explained: "And so this fourth year I've learned that I'm actually here to learn something about myself."

Mika, Peter, and RC's responses emphasized the perceived openness of the college experience. Students hoped to engage in processes of self-discovery and emerge from college with a better understanding of who they wanted to be and what they wanted to be about. These students expressed these expectations of college with a real sense of freedom. They sincerely believed that they controlled the paths they took. Violet, a secondgeneration Vietnamese, offered a different take on what students understood to be possible:

Well I wanted to-well, my parents actually wanted me to pursue the medical field and so I was going to give that a shot even though I didn't have a real passion for like biology or anything in the medical field. And so I came here initially as a bio major and I wanted to go and get my 4-year degree and then hopefully apply to medical school.

Violet's careful correction of word choice (i.e. "I wanted to-well, my parents actually wanted me to ...") indicates that she was still able to distinguish between her own desires and what her parents wanted, yet it was clear that her parents significantly influenced her expectations.

Parents played a key role in the development of students' expectations. Unlike Violet, however, other students were less able to distinguish between their parents' expectations and their personal aspirations. The line between what others expected of them and what they personally expected was often blurred. Indeed, students' personal hopes and aspirations, or as I have called them, internal expectations, are but one piece of a larger picture of expectations. In addition to their own aspirations, many Asian American students are negotiating a number of factors/pressures/influences from outside themselves, that is, external expectations.

\section{External Expectations}

The sources of external expectations are numerous, and at times they even overlap. Some external expectations are difficult to pinpoint while others have a very clear origin. In addition to the fact that external expectations take on different forms and emerge from different sources, the ways that students make sense of and handle these expectations also widely vary. In this section, two of the most influential sources of expectations will be discussed. The first is family. Particular attention is given to parents who were by far the most significant influence on the majority of the students in this study; other notable family relationships include siblings and cousins. Second, societal expectations of Asian American college students are explored. Larger shared meanings of Asian American racial identity, popular meanings of higher education, and the combined impact of these meanings on the students are examined. Throughout these discussions, I will address the ways that the participants in this study negotiated and managed the various external expectations with their own internal expectations.

Parental Expectations. One of the most striking findings of this study was the significant role of students' families, especially parents, in students' lives. There were two primary types of external expectations that students in this study received from their parents. The first type of parental expectation was regarding student behavior. The second type of external expectation from parents was regarding academics, including students' 
choice of major and career paths. In addition to these various types of parental expectations, there were a variety of ways parents relayed their expectations to their children (i.e., explicit or implicit/indirect) as well as different ways that the students made sense of and dealt with these expectations (i.e., internalizing, ignoring, or negotiating/balancing).

Behavior and Social Life. In precollege years, students' behaviors were more carefully monitored by their parents. Such was the case for Tawny, a second-generation Taiwanese and Chinese American, who shared how partying, drinking alcohol, and smoking pot were things she did not do before attending college: "People usually didn't do that because . . . your parents always tell you like: 'No, don't do that. That's bad.'” However, when students left home for college, the close monitoring of behavior nearly disappeared. In fact, there was very little direct instruction from parents regarding what students should do or not do in terms of which activities to engage in and who to hang out with. This was partially due to the fact, or perhaps even as a result of the fact, that students did not share much about their social lives with their parents. Also contributing to this less intense engagement between students and parents around social life issues was the fact that parents did not ask about these things.

Many of the students interpreted the decrease in direct involvement in their lives as a sign of their parents' giving them freedom and independence. The decreased engagement in students' social lives did not imply, however, that parents did not care about their children's social lives. And this was certainly not to say that parents had no expectations of their children's behavior. In fact, students did carry around a sense of what their parents would think most appropriate. At the same time, participants frequently spoke of ideas of independence and freedom, which they understood in different ways. For some, freedom was something parents gave. College was a time during which control was transferred from parents to students, at least in theory.

Beverly, a first-generation Chinese, explained her understanding of how and why her parents gave her freedom:

They're less involved, I would say, because since I came to college, they think it's time for me to learn how to be independent, so they give me so much more freedom. And they're like, "You're growing up. You know what to do now. You know what's right and what is not" ... They refuse to tell me what to do anymore, because they think I should make the choice and learn it myself.

Similar to other participants, Beverly viewed her independence as the ability to do, or not do, things as she saw fit.

Whether or not students felt like they were ready, college was the space and time when they gained this independence. Insofar as students negotiated their actions with parental expectations, many of the participants seemed to understand and accept that as long as they were able to meet their parents' academic expectations (i.e., emerging from college with a particular major and on a path towards a particular career), their social lives were theirs to manage. In other words, students' social behavior was monitored through their academic success. At the same time, this was students' time for freedom and independence, but only to the extent that freedom and independence meant control over day-to-day decisions about how to live, what to do, and with whom to socialize. For some students, this notion of freedom carried into their academic life as well as their choice of majors and careers. For others, freedom and independence in the academic realm was a bit more limited because of much more intense (and even oppressive) expectations from their parents. 
Academics. To a much greater extent than with expectations of behavior, students received messages from their parents regarding academics. The realm of "academics" refers to students' choices of majors and subsequent career paths as well as, though to a lesser degree, grades earned in courses. It was interesting to see all the different ways parental expectations were revealed, because although some were overt, most of these expectations were manifested in implicit and indirect ways. Whether explicit or implicit, the majority of respondents were, to varying degrees, forced to deal with parental expectations of their majors and career paths.

Explicit Expectations: Academics. In general, photo journalers did not take many pictures in reference to school and the formal processes of education. This tendency made Suri's photograph titled "The Library" even more compelling. The photograph depicts the front doors and front steps of West University's main library. The name of the library, which is on the front of the building, is centered in the image and one of the first aspects of the image to which the eye is drawn. Suri, a secondgeneration Laotian, captured the image of the outside of the main campus library in order to symbolize what first comes to mind when she thinks of West University. She further explained, "I took this image because whenever I first think of West University I think about what my parents always remind me, which is study." Suri also shared how she was always at the library, and the library had become a space associated with studying, the primary activity her parents explicitly expected her to engage in.

This may seem like an obvious, even unnecessary, observation; however, I chose to include these findings regarding parents' emphases on academics, because we should not assume they are or will always be the case. Although academics were emphasized for a number of students, there were also a number of students for whom there was flexibility and freedom to engage in college life as they pleased.

Academic achievement is significant for many Asian American students, with some parents imparting their expectations toward their children's academic achievement. In far more animated terms than Suri's descriptions, Cathy, a 1.5-generation Chinese, began her explanation of her parents' influence by adamantly stating, "My dad and I both have something in common: we're very stubborn. I'm really driven my way," emphasizing the "my" in "my way." "But my dad has a little influence on me, because he's the one who's like, um ..." At this point Cathy took a long pause, then under her breath she let out a sound of disgust. "Ugh!" she uttered. "I hate this!" Cathy continued in the matter-of-fact tone she previously used: "The truth is he's like, 'Make sure you get As this quarter.' He just gives me constant reminders that the number-one thing he cares about is my grades, that I do well." Cathy paused again and added, "And my mom doesn't really influence that much.” Cathy's descriptions of her parents' influence on her academic life suggested resentment toward them, especially her father. At the same time, she made sense of her parents' varying levels of academic expectations on their own level of education. Cathy explained that her father had attended an Ivy League school, and her mother had attended a state university. Even while harboring frustration with her father, Cathy seemed to be trying to figure out ways to proceed with college life in spite of her parents' expectations; at that particular time however, she was still wrestling with all of it.

Violet's situation was a bit different. Violet's parents were also very clear about what they expected of her. Before attending West University her parents had, by far, the most influence on her life: 
I feel like I was going to school basically, though, to kind of make them happy. And I mean I know that it was beneficial to myself as well, but I just felt like I was so pressured to do well. . . . My parents always try to advise me that they want the best for me, and that they want me to live a better life than what they had to experience. So, I mean I really look up to that.

Even after she left home for college, Violet's parents continued to be the predominant influence in her life. Similarly, for a number of students in this study, parental expectations regarding academics were extremely clear: students were expected to be academically successful, and their undergraduate degree would translate into a financially secure job. In some cases, parents also had very specific expectations of the academic majors and career trajectories their children should have. This was one aspect of students' lives in which parents still felt like they had the right to control, or at least to have significant influence. As much as they were able, most students allowed their parents' wishes regarding choice of major and career path to prevail. This, of course, often depended on students' success and even interest in the courses, majors, and careers their parents found desirable.

Students made sense of their parents' strong opinions regarding their academic life in different ways. In Violet's case, she reflected on how much her parents had accomplished as immigrants in the US and all they had done for her:

I understand now why they were pushing me so hard. They've come a really long way-I mean coming to America. ... The experiences that they tell me [make me feel] I'm so lucky and so I just want to be able to like show them that I am taking advantage of everything they've provided for me.
By comparing her own academic pursuits, particularly any struggles she faced in classes, with her parents' struggles of immigration and the difficulties of settling in a new country, Violet viewed her own struggles in college as having less weight. As a result, she accepted and followed her parents' desires to the best of her ability out of a sense of appreciation for her parents' sacrifices and because she felt as though this were something she owed her parents.

Implicit Expectations: Academics. What became increasingly clear was the significant influence that parents had on these students. Some of these expectations were more indirect than explicit; and students were often left to their own devices to translate and negotiate these implicit expectations. In some cases, students did not seem to feel the weight of their parents' expectations at all. Such was the case for Mika who explained how her parents are "the greatest influence in her life." At the same time, she also was careful to qualify this comment by adding that her parents are "not burdensome." Mika seemed to understand that there is a fine line between parents having significant influence on their children's lives and parents being overbearing; she was careful to point out that her situation was the former.

While some parents did directly express their expectations, the majority of students recounted becoming aware of these expectations through implicit or less direct ways. There were several students who shared that their families never pressured them, even about academics. This was the case for RC; however, only a few minutes after declaring his family never pressured him, RC spoke about his family viewing him as "perfection" and a "perfectionist." He went on to explain how his family saw him as always doing the right thing and always being good. Because of this image, RC felt that his family used a higher standard to judge his actions, and he felt like 
he had to live up to that high standard. In a similar situation Kyle, a second-generation Vietnamese, stated that he never felt pressured from his parents, but they did tell him to do his "academic best."

Both RC and Kyle vacillated between stating that they did not feel any pressure from their parents to later making comments that were infused with parental expectations. These apparent contradictions may be a result of students' desires to be perceived as making their own choices. These young adults were also coming into their own and would want to appear and feel like they were in control of their lives. Moreover, the expectations and pressures from their parents may have been so deeply embedded in them that they operated without being fully aware of the extent to which their parents' expectations have dictated their own expectations.

Other students clearly, though indirectly, perceived their parents' expectations. Tawny "sensed" that parents wanted her to enter a "practical field," such as science, engineering, or business, because those fields would translate into high-paying jobs. Lisa's parents did not explicitly tell her what to do, yet she still felt pressured to do well academically and pursue certain majors and fields. She shared how her father would talk about other family members or friends and comment, "So-andso's kids do this." Then he would look at her and ask, "What are you doing?" Both Lisa and Tawny had clear ideas of what they thought their parents expected of them; however, the ways that these expectations became embedded in their minds were less clear. Lisa attributed the roundabout way in which her father questioned her choice of major and career path to "Asian cultural values": that is, Asian parents want their children to be smart or to excel in fields that lead to highly lucrative jobs. Lisa's example also highlights another pattern among the respondents, namely the interesting dynamic between fathers and daughters; in fact, quite a few of the female respondents made comments about their fathers.

Negotiating Expectations From Parents and Family. There was a wide range of ways in which the students in this study managed differences between their parents' expectations and their own aspirations. In some cases, students internalized their parents' expectations in such a way that their parents' expectations became their own. Beverly declared, "Their expectation is always my motivation." Sophia gave a similar response and asserted, "Usually my parents' expectations are my aspirations." Conversely, other students like Bianca and Peter shared how they managed differences in expectations by simply ignoring their parents.

Research on the impact of generational status on parent-child relationships have found that more recently immigrated Asian parents tend to have much stronger and more explicit expectations of their children, and these children tend to follow suit (e.g., Kao, 2002; Louie, 2004b). As such, the difference in participants' responses may be attributed to differences between multigenerational Asian Americans and more recent Asian immigrants. For example, Beverly and Sophia were both first-generation Asian Americans, while Bianca and Peter were second-generation; yet there were no noticeable patterns regarding expectations among the different generations. In fact, there was a wide range of responses within and among different generations. Instead of focusing on the role of generational status, I chose to focus on a more salient finding: the persistence of parental influences.

Although it may seem as though I am revisiting age-old discussions of the influences of Asian (and Asian American) families, particularly parents on their children, this study differs from previous studies on parental roles in that their influence was not assumed. In fact, I was expecting to find greater autonomy, 
especially regarding parental influence, among the current cohort of college students than that of previous generations. Also, I focused on how students understand, contest, and negotiate their parents' expectations. The ways students talked about their parents' expectations revealed the ways in which parents' hopes for greater opportunity for their children through college attendance primarily meant increased social mobility and financial security. This tendency resonates with existent research on the children of immigrants and the tendency for them to perceive high expectations from their parents and/or feel significant pressure from their parents to pursue certain career paths (e.g., Portes \& Zhou, 1993; Suárez-Orozco \& Suárez-Orozco, 2009; Tuan, 2004; Zhou, 1997; Zhou \& Xiong, 2005). Even though some of the findings from this study align with existing research that highlights the crucial role that families play in the lives of Asian American students, and even though I anticipated parents having some influence on their children, I was not expecting the large extent to which parents impacted these students' lives.

Before entering college, parents were by far the most significant influence on these students; throughout their time in college, it seemed as though parental influence continued, albeit it in different forms and to differing extents. For example, some students directly negotiated with their parents. These negotiations included verbal negotiations, even intense arguments, during which students tried to get their parents to see their point of view and vice versa. One of the most prevalent issues students had to negotiate was their choice of major and future occupation. Several of the students chose majors and career paths that embodied a bit of both worlds-both what their parents wanted for them and what they wanted or enjoyed. Some students chose academic majors with their parents very much in mind. For instance, Liz, a first-generation
Asian American (part Italian, part Japanese), had been interested in studio art and design; however, she entered West University as a psychology major because she felt that choice of major was a "safer" direction to take: she felt she owed so much to her parents and did not want them to worry. Subsequently, Liz's choice of psychology as her major was a compromise.

Societal Expectations. The expectations I have described are not unlike those of other college students, regardless of race. So, how do students' racial identities, particularly an Asian American racial identity, fit into this picture? Some might argue that Asian American students experience greater parental influences and pressures than their non-Asian peers (Lin \& Fu, 1990; Stevenson \& Lee, 1990). For the most part these perspectives offer limited understandings of Asian American students' experiences and contribute to a narrow perception of the relationship between Asian culture and educational experiences in America; instead, as this study's participants demonstrated, students negotiate and, at times, maneuver around their parents' expectations. Although these navigational processes are certainly not exclusive to Asian Americans, the interaction between Asian American students and campus space results in uniquely Asian American processes because their expectations, and subsequently their choices, are framed by their understandings of what it means to be Asian American.

Violet explained what it was like to literally negotiate her expectations with those of her father:

It's kind of hard though because my dad has this mentality, well, (and it's true too) that whenever I would say: "It's my life!" then he'd always say (and I guess it's in the Asian culture), "It's not about only your life, but your life affects me, your life affects your mom, it affects the entire family." 
I should point out that the two parenthetical phrases from this quote reveal how Violet was making sense of her father's perspective. First, Violet shows her agreement with her father's perspective by adding: "and it's true too." This comment aligns her not only with the perspective, but with her father as well. And second, Violet's comment about her father's perspective as being part of "the Asian culture" connects her parents' expectations with meanings of Asianness or Asian Americanness: she understands her parents' expectations through this particular orientation.

Along with managing a variety of internal and external expectations, Asian American college students must also negotiate an additional external expectation from society: what it means to be Asian American; that is, meanings and expectations of Asian American racial identity become even more pronounced and complicated in college, a space imagined to be full of freedom and possibility (Samura, 2011). Moreover, this occurs at a moment when the US is supposedly becoming "postracial." Even before entering college, a space and time known to elicit racial awareness (Alvarez \& Yeh, 1999; Kibria, 2000; Louie, 2004a; Phinney, 1992), Asian American students are confronted by what it means to be Asian American in college.

Many of the students in this study became aware of these societal expectations of meanings of Asian American racial identities through racial stereotypes that portrayed students who were often expected to be a certain type of Asian or Asian American which included a set of particular behavioral expectations. For example, participants cited the model minority stereotype as one common source of a number of these expectations and pressures. I should note that explicit use of the term model minority was used by only a handful of students; however, the characteristics and attributes typically associated with the model minority image did emerge in a number of students' interviews and photo journals but were primarily understood to be merely an aspect of Asian Americanness. At times, the model minority image framed how Asian Americans students were viewed by their peers; for example, Tiffany shared about the racial comments she heard from her classmates: "I overheard a guy say, when we were creating group work, 'Oh, partner up with her. She's Asian, she must be smart.' And I was just like, "Wow."

Violet also briefly commented on the model minority stereotype:

I do think it's draining. I think when you have this image that everyone expects of you, I think that it shapes you as an Asian American and the way people see you also. ... I think it puts a lot of pressure on people, definitely, . . . to try to achieve those expectations.

Even though the expectations imposed by the model minority image are based on false premises (e.g., all Asians are smart), the stereotype continues to impact what society expects of Asian Americans (Lee \& Kumashiro, 2005). Asian American students, such as the ones in this study, frequently take on these expectations of race and even attempt to embody the racial stereotype. Not only was the model minority image a source of students' expectations, pressures of the stereotype also affected their understandings of and discourse surrounding their expectations and their parents' expectations.

The acceptance and embodiment of the model minority stereotype by Asian Americans is an area of research that is gaining attention. A small but increasing number of scholars have looked at the various ways that Asian Americans internalize the model minority stereotype and the subsequent impact on attitudes and actions (e.g., Kibria, 2000; Yang, Byers, Ahuna, \& Castro, 2002). In my study, 
meanings of Asian American-ness affected students' expectations by enabling them to see opportunities in a particular way. In some cases, the model minority image framed their choices so that there were boundaries or limits to the directions students believed they could or should take. What is important to take away from this brief discussion of the influence of the model minority image is the fact that it is only one of several factors that students considered as they negotiated their expectations. By no means was it an insignificant factor: it was certainly an influential expectation; however, the expectations students brought to college were not fixed and often underwent significant modifications.

Negotiating Societal Expectations. One of the most common ways in which the students in this study negotiated society's expectations of them was by making conscious efforts to separate themselves from characteristics associated with stereotypical Asians. The students in this study had an understanding of what "other Asians" in college were like, and they attempted to distance themselves from those perceived types of Asians. In fact, a number of respondents talked about how they were different from, or at least attempted to differentiate themselves from, other Asians on campus. They saw themselves as breaking Asian stereotypes, or at least what they understood Asianness or Asian Americanness to mean. For example, Ella, a third-generation Chinese, shared how she watched a number of her Asian American peers "live the stereotype." As a result, she consciously chose paths that, in her mind, were different from stereotypical Asians, such as avoiding majors in science, engineering, mathematics, or technology.

Similarly, Cathy saw herself as taking "the road less travelled." According to Cathy, she came to West University instead of going to another university that had a high number of Asian students, because she felt that Asians at this campus need a good representation. She further explained that she wanted to "help be a piece that represents Asians here [at West University].” Ella and Cathy's sentiments were similar to a number of other participants who recognized the expectations that were placed on them by society because of their race. These students chose to consciously address these expectations of race by steering clear of what might be considered stereotypical Asian. This impacted their choice of majors, their circles of friends, and the types of activities in which they engaged. At the same time, however, students continued to refer to Asian stereotypes, such as the model minority image, to talk about and measure their deviation from such stereotypes.

Part of students' efforts to position themselves as different from "other Asians" may have had to do with the fact that they were at a university that had a relatively small Asian population compared to other schools in the same university system. In this space, they were racial minorities, and their Asianness was more evident. A majority of the participants saw themselves as breaking stereotypes in a general, rhetorical way as well as in ways that they thought might impact the opinions of their non-Asian peers. In doing so, however, they reified the meanings and views of Asian Americanness from which they tried to distance themselves.

\section{CONCLUSION AND IMPLICATIONS}

This study contributes to scholarship on Asian American college students in at least three important ways. First, this inquiry offers further insight into how Asian American college students navigate and negotiate higher education by examining in depth the variety of expectations they wrestle with. Not only were different types (i.e., internal and external; implicit and explicit) and sources (i.e., parents; society) of expectations identified, but the 
ways students made sense of and negotiated differences between expectations also were traced. All the students in this study created some form of compromise in an attempt to balance internal and external expectations. For some students, the negotiation process meant that they internalized external expectations. Other students prioritized internal expectations over external expectations, or vice versa.

The range of responses suggest that Asian American college students' experiences today are quite diverse and require careful consideration of the differences that exist within the Asian American racial category. Further research is needed to document and capture the variations of expectations with which Asian American college students wrestle. Also, students' responses indicated their own lack of certainty regarding different sources of expectations in their lives. For instance, in several of the interviews, students shared about the abundant amount of freedom they have in college, only to later disclose the pervasive role of their parents' expectations in their lives. This information is useful for higher education administration and student affairs practioners as they consider the kinds of supports and resources Asian American college students may need as they wrestle with and negotiate various expectations. For example, career development services may be able to provide more effective advising of Asian American college students, including asking more nuanced and informed questions about students' interests and plans.

Second, this study provided further insight into the role of students' families, especially their parents. Findings from this research indicate that parental expectations continue to affect students' decisions. Even as the forms in which parents' expectations are transmitted changed, the persistence of external expectations from parents remained. Instead of more explicit demands, parents transmitted their hopes to their children in more subtle ways, such as making comparisons between the students and the children of friends or family members. The extent to which parents continuously and significantly influenced students' lives was unexpected, particularly the lack of a noticeable difference among different generations. This is an area of research that warrants further investigation. For example, it would be useful to examine how the role of parents changes (or not) throughout students' college tenure and beyond; future research on this topic may want to conduct longitudinal studies on the role of family and parents' expectations in Asian American students' lives.

Finally, this study revealed how, in addition to parental expectations, Asian American students also contend with societal expectations of Asian Americans (via racial stereotypes) as being high academic achievers destined to attend college and successfully graduate. The variety of external expectations and internal expectations discussed in this article translate into a particular understanding of "freedom" they carry into college. This perspective of freedom and possibility seems to transfer over into students' understandings of the importance of race in their lives. The students in this study indicated a desire to break or resist Asian American stereotypes. This meant that students initially chose their college, academic major, and/or social groups, not only to satisfy their negotiated parental expectations, but also to distance themselves from what many students called "typical Asians." Future research on college choice may want to explore Asian American students' efforts to break racial stereotypes or position themselves in strategic ways. By further examining the wide range of Asian American college students' experiences and perspectives, especially over time, institutions of higher education may more effectively serve a population about which there is still much to be learned. 
Correspondence concerning this article should be addressed to Michelle Samura, College of Educational Studies, Chapman University, One University Drive, Orange, CA 92866; samura@chapman.edu

\section{REFERENCES}

Alvarez, A. N., \& Yeh, T. L. (1999). Asian Americans in college: A racial identity perspective. In D. Sandhu (Ed.), Asian and Pacific Islander Americans: Issues and concerns for counseling and psychotherapy. Huntington, NY: Nova Science.

Collier, J., \& Collier, M. (1986). Visual anthropology: Photography as a research method. Albuquerque, NM: University of New Mexico Press.

Delaney, D. (2002). The space that race makes. The Professional Geographer 54. 1.

Feliciano, C. (2006). Beyond the family: The influence of premigration group status on the educational expectations of immigrants' children. Sociology of Education, 79, 281-303.

Hurtado, S., Milem, J. F., Clayton-Pedersen, A. R., \& Allen, W. R. (1998). Enhancing campus climates for racial/ethnic diversity: Educational policy and practice. Review of Higher Education, 21, 279-302.

Kao, G. (2002). Ethnic differences in parents' educational aspirations. In B, Fuller \& E. Hannum (Eds.), Schooling and social capital in diverse cultures (pp. 85-103). Oxford, England: Elsevier Science.

Keup, J. R. (2007). Great expectations and the ultimate reality check: Voices of students during the transition from high school to college. NASPA Journal, 44, 3-31.

Kibria, N. (2000). Race, ethnic options and ethnic binds. Sociological Perspectives, 43, 77-95.

Knowles, C. (2003). Race and social analysis. Thousand Oaks, CA: SAGE Publications.

Kvale, S. (1996). InterViews: An introduction to qualitative research interviewing. Thousand Oaks, CA: SAGE.

Lee, S. J., \& Kumashiro, K. (2005). A report on the status of Asian American and Pacific Islanders in education: Beyond the "model minority" stereotype. Washington, DC: National Education Association of the United States Human and Civil Rights.

Lin, C. Y., \& Fu, V. R. (1990). A comparison of child-rearing practices among Chinese, immigrant Chinese, and Caucasian American parents. Child Development, 61, 429-433.

Lipsitz, G. (2007). The racialization of space and the spatialization of race: Theorizing the hidden architecture of landscape. Landscape Journal, 26, 1-07.

Louie, V. (2004a). Compelled to excel: Immigration, education and opportunity among Chinese Americans. Palo Alto, CA: Stanford University Press.

Louie, V. (2004b). Being practical or doing what I want: The role of parents in the academic choices of Chinese Americans. In P. Kasinitz, J. Mollenkopf \& M. Waters (Eds.) Becoming New Yorkers: The second generation in a global city (pp. 79-109). New York, NY: Russell Sage Foundation.

Massey, D. (1994). Space, place, \& gender. Minneapolis, MN: University of Minnesota Press.
Miller, T., Bender, B., \& Schuh, J. (2005). Promoting reasonable expectations: Aligning student and institutional views of the college experience. San Francisco, CA: Jossey-Bass.

Phinney, J. S. (1992). The multigroup ethnic identity measure: A new scale for use with diverse groups. Journal of Adolescent Research, 7, 156-176.

Portes, A., \& Zhou, M. (1993). The new second generation: Segmented assimilation and its variants. Annals of the American Academy of Political and Social Science, 530(1), 74-96.

Samura, M. (2011). Racial transformations in higher education: Emergent meanings of Asian American racial identities. In X. L. Rong \& R. Endo (Eds.) Asian American Education: Identities, Racial Issues, and Languages. Charlotte, NC: Information Age Publishing, Inc.

Schilling, K. M., \& Schilling, K. L. (2005). Expectations and performance. In M. Upcraft, J. Gardner, \& B. Barefoot (Eds.), Challenging and supporting the first-year student: $A$ handbook for improving the first year of college. San Francisco, CA: Jossey-Bass.

Smith, J., \& Wertlieb, E. (2005). Do first-year college students' expectations align with their first-year experiences? NASPA Journal, 42, 153-174.

Stevenson, H., \& Lee, S. Y. (1990). Contexts of achievement: A Study of American, Chinese, and Japanese Children. Monographs of the Society for Research in Child Development, 55 (1-2, Serial No. 221).

Strauss, A., \& Corbin, J. (1998). Basics of qualitative research: Techniques and procedures for developing grounded theory. Thousand Oaks, CA: SAGE.

Suárez-Orozco, C., \& Suárez-Orozco, M. M. (2009). Children of immigration. Cambridge, MA: Harvard University Press.

Suchar, C. (1997). Grounding visual sociology in shooting scripts. Qualitative Sociology, 20, 33-55.

Terenzini, P., Springer, L., Yaeger, P., Pascarella, E., \& Nora, A. (1996). First-generation college students: Characteristics, experiences, and cognitive development. Research in Higher Education, 37, 1-22.

Tuan, M. (2004). Assimilation redux. Du Bois Review: Social Science Research on Race, 1, 389-392.

Yang, R., Byers, S., Ahuna, L., \& Castro, K. (2002). Asian American students' use of a university student-affairs office. College Student Journal, 36, 448-470.

Zhou, M. (1997). Growing up American: The challenge confronting immigrant children and children of immigrants. Annual Review of Sociology, 23, 63-95.

Zhou, M., \& Xiong, Y. S. (2005). The multifaceted American experiences of the children of Asian immigrants: Lessons for segmented assimilation. Ethnic and Racial Studies, 28, $1119-1152$. 